\title{
Effect of Low Pressure Application during Solidification on Microstructure of AlSi Alloys
}

\section{Richard Pastirčák}

Department of technological engineering. Faculty of Mechanical Engineering, University of Žilina, Univerzitná 1, 01026 Žilina, Slovak Republic. richard.pastircak@fstroj.uniza.sk

This study investigated the effects of squeeze parameters on the properties of squeeze castings and the optimum parameters for producing squeeze castings from $\mathrm{Al}-\mathrm{Si}$ alloy. It also compared the properties of the squeeze castings with those of chill castings. Squeeze castings were made from AISi7Mg0.3 alloy using pressures of 15-22.5-30MPa with the alloy poured at $680,700,720$ and $740^{\circ} \mathrm{C}$ into a die preheated to 150,200 and $250{ }^{\circ} \mathrm{C}$. Squeeze time was $10 \mathrm{~s}$. At the pressure effect during crystallization there is possible to observe the refinement of eutectic silicium with the increasing pressured. Eutectic Si is excreted in clusters in comparison with non-influenced structure. There comes to increasing of failure strength and mainly of elongation. The hardness of investigated samples was not changed markedly. At the pressure of $15 \mathrm{MPa}$ there comes to inadequate pressure influence, what causes the creation of shrinkage in the longitudinal part of the sample. This decreases the mechanical properties.

Keywords: microstructure, low pressure, alloy $\mathrm{AlSi} 7 \mathrm{Mg} 0.3$

\section{Acknowledgements}

This work was created within the solution of the Operational Programme for Research and Development of ITMS code 26220220047. The authors thank the Grant Agency for support.

\section{References}

[1] NOVÁ, I., MACHUTA, J. 2013. Squeeze casting results of aluminium alloys. In.: Manufacturing technology. ISSN 1213-2489, Vol. 13, No. 1(2013), pp. 73-79.

[2] RAGAN, E. et al. 2007. Liatie kovov pod tlakom. Vydavatel'stvo Michala Vaška, 2007. 392 s. ISBN 978 - 80 $8073-979-9$.

[3] NOVÁ, I., NOVÁKOVÁ, I., MACHUTA, J. 2011. Aluminium alloys squeeze casting. In.: Slévárenství. ISSN 1213-2489, Vol. LIX, No. 9-10(2011), p. 304-308.

[4] MICHNA, Š. - NOVÁ, I. 2008. Technológia a spracovanie kovových materiálov. Adin, s.r.o. Prešov. ISBN 978 $-80-89244-38-6.336 \mathrm{pp}$.

[5] BOLIBRUCHOVA, D. 2010. Casting technology. GEORG Žilina, ISBN 978-80-89401-14-7, 248 pp.

[6] BOLIBRUCHOVÁ, D., RICHTÁRECH, L. 2013. Effect of adding iron to the AlSi7Mg0.3 (EN AC 42 100, A356) alloy In: Manufacturing technology. ISSN 1213-2489. Vol. 13, No. 3, p. 276-281.

[7] EPERJEŠI, L'. et all. 2013. Influence of returning material on porosity of die castings. In: Manufacturing Technology. ISSN 1213-2489. Vol. 13, No. 1, p. 36-39.

[8] MALIK,J., FUTÁŠ,P., VASKOVÁ,I., EPERJEŠI,Š. 2007. Vplyv technologických faktorov liatia na kvalitu odliatkov zo silumínu. Slévárenství, ISSN 0037-6825. No..4-5, p.259-262.

[9] BRŮNA,M., KUCHARČÍK, L. 2013. Prediction of the Porosity of Al Alloys. In: Manufacturing Technology. ISSN 1213-2489. Vol. 13, No. 3, p. 296-302.

[10] BOLIBRUCHOVÁ, D., RICHTÁRECH, L. 2013. Effect of adding iron to the AlSi7Mg0.3 (EN AC 42 100, A356) alloy. In: Manufacturing Technology. ISSN 1213-2489. Vol. 13, No. 3, p. 276-281. 